\title{
Influence of Cutting Speed, Feed Rate and Bulk Texture on the Surface Finish of Nitrogen Alloyed Duplex Stainless Steels during Dry Turning
}

\author{
D. Philip Selvaraj ${ }^{1}$, Palanisamy Chandramohan ${ }^{2}$ \\ ${ }^{1}$ Faculty of School of Mechanical Sciences, Karunya University, Coimbatore, India \\ ${ }^{2}$ Faculty of Mechanical Engineering, Coimbatore institute of Engineering and Technology, Coimbatore, India \\ E-mail:de_philip@rediffmail.com,pcmohu@yahoo.co.in \\ Received February 1, 2010; revised March 19, 2010; accepted March 25, 2010
}

\begin{abstract}
This paper presents the results of experimental work carried out in dry turning of cast duplex stainless steels (ASTM A 995 Grade4A and ASTM A 995 Grade5A) using TiC and TiCN coated cemented carbide cutting tools. The turning tests were conducted at five different cutting speeds $(80,100,120,140$ and $160 \mathrm{~m} / \mathrm{min})$ and three different feed rates $(0.04,0.08$ and $0.12 \mathrm{~mm} / \mathrm{rev})$ with a constant depth of cut $(0.5 \mathrm{~mm})$. The influence of cutting speed and feed rate on the machined surface roughness was investigated. Texture analysis (Bulk) was also carried out to study the impact of preferred orientation on the resulting surface roughness. The result reveals that the increasing cutting speed decreases the surface roughness till a particular point and then increases whereas; the surface roughness value decreases with the decreasing feed rate. Presence of alpha fiber (Bulk texture analysis) in the austenite phase of $4 \mathrm{~A}$ work piece material leads to better surface finish. Among both the grades, surface finish of grade $4 \mathrm{~A}$ is better than grade $5 \mathrm{~A}$ work piece material.
\end{abstract}

Keywords: Surface Roughness, Duplex Stainless Steel, Dry Turning, Coated Carbide Tool

\section{Introduction}

Over the past two decades, the applications of stainless steel materials have increased enormously in various fields. The attractive combination of excellent corrosion resistance, a wide range of strength levels including strength retention at cryogenic and elevated temperatures, good formability, and an aesthetically pleasing appearance have made stainless steel materials the preferred choice for a diverse range of applications, from critical piping components in boiling water nuclear reactors to the ubiquitous kitchen sink [1].

Machinability is a measure of ease with which a work material can be satisfactorily machined. The machinability aspect is of considerable importance for production engineers to know in advance about the machinability of a work material so that the processing can be planned in an efficient manner [2]. Ferritic stainless steels (FSS) are known for their corrosion resistance and Austenitic stainless steels (ASS) for better mechanical properties like strength and deep drawability. But their machinability is more difficult than other alloy steels due to the reasons like low heat conductivity, high built up edge tendency, high deformation hardening etc. Duplex stainless steel (DSS) is a material that combines the benefits of both FSS and ASS by proper balancing of ferrite and austenite. It is apparent that a balance of ferrite and austenite phase in a microstructure made it realistic for applications, which demand better corrosion resistance and improved mechanical properties [1].

Ibrahim Ciftci investigated the Machining characteristics of austenitic stainless steels (AISI 304 and AISI 316) using CVD multi layer coated carbide tools. The influence of work piece grade, cutting tool coating top layer and cutting speed were investigated on cutting forces and machined surface roughness. With increasing cutting speed the surface finish values decrease until a minimum value and beyond which they increase [3]. Ihsan Korkut et al. carried turning tests to determine optimum machining parameters for machining of austenitic stainless steel. Surface roughness values were found to decrease with increasing cutting speeds [4]. The active wear and failure mechanism of TiN coated cemented carbide tools with internal coolant supply when drilling of HIP ed P/M Duplok 27 and conventionally produced stainless steel ASTM A81901A was investigated by Jukka Paro et al. 
In $\mathrm{P} / \mathrm{M}$ produced duplex stainless steel there are more hard oxide particles causing machining difficulties from the wear point of view. High strength and work hardening rate also cause difficulties from the machining-point of view [5]. Effects of free cutting additives such as $\mathrm{S}$, $\mathrm{Ca}, \mathrm{Cu}$ and $\mathrm{Bi}$ on the machinability of work materials SUS303, SUS303Cu, SUS304 and SUS316 were studied by Akasawa et al. The resulfurization deteriorated the surface texture at lower cutting speeds in dry cutting. Calcium treated steels with inclusions of an anorthite composition exhibited a better surface than those of plain austenitic steels [6].

Machining of cast austenitic Stainless steels with carbide tools were studied by Agrawal et al. The relative performance of coated and uncoated carbide tools in the machining of cast austenitic Stainless steels were assessed with reference to cutting force requirement (both horizontal force $-\mathrm{P}_{\mathrm{x}}$ and vertical force $-\mathrm{P}_{\mathrm{z}}$ ), tool rakeface wear and chip characteristics. It was reported that the composition of stainless steel work piece influences machinability [7]. Machinability of austenitic Stainless steel SS303 was investigated by O'Sullivan and Cotterell. An on-line detection technique (Acoustic Emission technique) was developed to detect the work hardenability of austenitic Stainless steels SS303 during machining [8]. Active tool wear and failure mechanisms of TiN coated cemented carbide tools while machining $\mathrm{X} 5 \mathrm{CrMnN} 18$ austenitic stainless steel, was investigated by Jukka Paro et al. By nitrogen alloying, austenite gets stabilized and the strength of austenitic stainless steel is increased, thereby work hardening is promoted. Higher N content decreases machinability [9].

Noordin et al. investigated the usability of coated TiCN based cermet and coated carbide cutting tools to turn tempered martensitic stainless tool steel with hardness in the range of 43-45 HRC under dry cutting conditions [10]. Thamizhmanii and Hasan investigated surface roughness and flank wear on hard AISI $440 \mathrm{C}$ material with different operating parameters using $\mathrm{CBN}$ and PCBN tools [11]. Anthony Xavior and Adithan investigated the influence of cutting fluids on tool wear and surface roughness during turning of AISI 304 with carbide tool. An attempt has been made to identify the influence of coconut oil in reducing the tool wear and surface roughness during turning process [12].

Texturing influences the properties of the work material to a remarkable extent. The extent of texture development in various steels, aluminium alloys and $\mathrm{Zr}-\mathrm{Nb}$ alloys has been studied by several researchers [13]. The major BCC and FCC texture components are listed by name, Euler angle and Miller indices $\{\mathrm{h} \mathrm{k} \mathrm{l}\}<\mathrm{u} \mathrm{v} \mathrm{w}>$ in the Table 1. The first indices $\{\mathrm{h} \mathrm{k} \mathrm{l}\}$ describe the crystallographic plane parallel to the sheet surface whereas the second indices $<\mathrm{u} \mathrm{v} \mathrm{w}>$ indicate the direction parallel to the rolling direction [14].

From the literature stated above, it becomes clear that
Table 1. Major BCC and FCC texture components.

\begin{tabular}{|c|c|c|c|c|c|}
\hline $\begin{array}{l}\text { CRYSTAL } \\
\text { LATTICE }\end{array}$ & NAME & $\varphi_{1}$ & $\Phi$ & $\varphi_{2}$ & $\begin{array}{r}\{\mathrm{hkl}\} \\
<\mathrm{uvw}>\end{array}$ \\
\hline \multirow{6}{*}{$\mathrm{BCC}$} & Rotated & & & & $\{001\}$ \\
\hline & Cube & $0^{\circ}$ & $0^{\circ}$ & $45^{\circ}$ & $\begin{array}{r}<110> \\
\{115\}\end{array}$ \\
\hline & Inverse & $0^{\circ}$ & $15^{\circ}$ & $45^{\circ}$ & $\begin{array}{r}<110> \\
\{112\}\end{array}$ \\
\hline & Brass & $0^{\circ}$ & $35^{\circ}$ & $45^{\circ}$ & $\begin{array}{r}<110> \\
\{111\}\end{array}$ \\
\hline & Inverse & $0^{\circ}$ & $55^{\circ}$ & $45^{\circ}$ & $\begin{array}{r}<110> \\
\{112\}\end{array}$ \\
\hline & Copper & $30^{\circ}$ & $55^{\circ}$ & $45^{\circ}$ & $\begin{array}{r}<110> \\
\{001\}\end{array}$ \\
\hline \multirow[t]{6}{*}{ FCC } & Cube & $0^{\circ}$ & $0^{\circ}$ & $0^{\circ}$ & $\begin{array}{r}<100> \\
\{011\}\end{array}$ \\
\hline & Goss & $0^{\circ}$ & $45^{\circ}$ & $0^{\circ}$ & $\begin{array}{r}<100> \\
\{011\}\end{array}$ \\
\hline & $\begin{array}{l}\text { Brass } \\
\text { Rotated }\end{array}$ & $35^{\circ}$ & $45^{\circ}$ & $0^{\circ}$ & $\begin{array}{r}<211> \\
\{011\}\end{array}$ \\
\hline & Goss & $90^{\circ}$ & $45^{\circ}$ & $0^{\circ}$ & $\begin{array}{r}<011> \\
\{123\}\end{array}$ \\
\hline & $\begin{array}{l}\text { S } \\
\text { C (Cop- }\end{array}$ & $59^{\circ}$ & $37^{\circ}$ & $63^{\circ}$ & $\begin{array}{r}<634> \\
\{112\}\end{array}$ \\
\hline & $\begin{array}{l}\text { per) } \\
\text { R-Com- } \\
\text { ponent }\end{array}$ & $90^{\circ}$ & $35^{\circ}$ & $45^{\circ}$ & $\begin{array}{r}<111> \\
\{123\} \\
<412>\end{array}$ \\
\hline
\end{tabular}

machinability studies have been carried out by various researchers in the cast and mechanically formed stainless steels. Still there remains some difficulty in the day to day machining activities of stainless steels; particularly in nitrogen alloyed duplex stainless steels. This reveals the fact that still more investigation needs to be carried out through a different procedure to find a reasonable solution.

Surface quality of the machined work piece is dependent on the grain orientation (Texture) of the base material and the cutting conditions used during machining process. Surface roughness is an important index to evaluate cutting performance in turning operation. It plays vital role in functioning and fatigue life of the component.

Therefore in this work, studies on machinability are carried out to understand the influence of the cutting speed, feed rate and work piece material (Bulk texture) on the surface finish of ASTM A 995 GRADE 4A and ASTM A 995 GRADE 5A cast duplex stainless steels during dry turning using $\mathrm{TiC}$ and $\mathrm{TiCN}$ coated cemented carbide tools.

\section{Experimental Procedure}

The work piece materials used were ASTM A 995 GRADE 4A and ASTM A 995 GRADE 5A cast duplex steel specimen in cylindrical form. The dimensions of the specimens were $300 \mathrm{~mm}$ length and $80 \mathrm{~mm}$ diameter. The chemical compositions and mechanical properties of the work piece materials are given in Tables 2 and $\mathbf{3}$ respectively. 
Table 2. Composition of ASTM A 995 GRADE-4A and 5A.

\begin{tabular}{ccccccccccc}
\hline Material & $\mathrm{C}$ & $\mathrm{Si}$ & $\mathrm{Mn}$ & $\mathrm{S}$ & $\mathrm{P}$ & $\mathrm{Cr}$ & $\mathrm{Ni}$ & $\mathrm{Mo}$ & $\mathrm{Cu}$ & $\mathrm{N}$ \\
\hline 4A & 0.028 & 0.650 & 0.710 & 0.006 & 0.027 & 22.160 & 5.660 & 3.330 & 0.140 & 0.240 \\
$5 \mathrm{~A}$ & 0.028 & 0.670 & 0.870 & 0.005 & 0.028 & 25.100 & 6.630 & 4.160 & - & 0.170 \\
\hline
\end{tabular}

Table 3. Mechanical properties of ASTM A 995 GRADE-4A and 5A.

\begin{tabular}{ccccc}
\hline Material & $\begin{array}{c}\text { Tensile Strength } \\
(\mathrm{MPa})\end{array}$ & $\begin{array}{c}\text { Yield Strength } \\
(\mathrm{MPa})\end{array}$ & $\begin{array}{c}\text { Elongation } \\
\%\end{array}$ & $\begin{array}{c}\text { Hardness } \\
(\mathrm{BHN})\end{array}$ \\
\hline $4 \mathrm{~A}$ & 732 & 595 & 30.2 & 212 \\
$5 \mathrm{~A}$ & 741 & 546 & 32.2 & 223 \\
\hline
\end{tabular}

Table 4. Experimental results for surface roughness.

\begin{tabular}{cccccc}
\hline $\begin{array}{c}\text { Exp } \\
\text { No }\end{array}$ & $\begin{array}{c}\text { Cutting speed } \\
(\mathrm{m} / \mathrm{min})\end{array}$ & $\begin{array}{c}\text { Feed rate } \\
(\mathrm{mm} / \mathrm{rev})\end{array}$ & $\begin{array}{c}\text { Depth of cut } \\
(\mathrm{mm})\end{array}$ & & \multicolumn{2}{c}{$\begin{array}{c}\text { Surface roughness } \\
(\mu \mathrm{m})\end{array}$} \\
\cline { 5 - 6 } & & 0.04 & 0.5 & 0.60 & 4A GRADE \\
2 & 80 & 0.04 & 0.5 & 0.53 & 1.20 \\
3 & 100 & 0.04 & 0.5 & 0.58 & 1.16 \\
4 & 120 & 0.04 & 0.5 & 0.72 & 1.27 \\
5 & 140 & 0.04 & 0.5 & 0.85 & 1.35 \\
6 & 160 & 0.08 & 0.5 & 0.68 & 1.17 \\
7 & 80 & 0.08 & 0.5 & 0.57 & 1.24 \\
8 & 100 & 0.08 & 0.5 & 0.60 & 1.30 \\
9 & 120 & 0.08 & 0.5 & 0.76 & 1.42 \\
10 & 140 & 0.08 & 0.5 & 0.93 & 1.32 \\
11 & 160 & 0.12 & 0.5 & 0.85 & 1.25 \\
12 & 80 & 0.12 & 0.5 & 0.64 & 1.30 \\
13 & 100 & 0.12 & 0.5 & 0.76 & 1.42 \\
14 & 120 & 0.12 & 0.5 & 0.89 & 1.48 \\
\hline
\end{tabular}

The machining tests were performed by single point continuous turning on a Kirloskar Turn master-35 medium duty lathe, with a variable speed of up to $1500 \mathrm{rpm}$ and a power rating of $3 \mathrm{HP}$. The tests were conducted without the application of cutting fluid (dry turning). The cutting tools used were $\mathrm{TiC}$ and $\mathrm{TiCN}$ coated carbide inserts produced by Tagutec and had SNMG 120408 MT TT5100 Tagutec designation. These inserts were clamped mechanically on a pin and hole type rigid tool holder with a general specification of PSBNR 2525M12. Cutting speeds used ranges from 80 to $160 \mathrm{~m} / \mathrm{min}$. The cutting speed was increased in steps of $20 \mathrm{~m} / \mathrm{min}$. Feed rates used ranges from 0.04 to $0.12 \mathrm{~mm} / \mathrm{rev}$. The feed rate was increased in steps of $0.04 \mathrm{~mm} / \mathrm{rev}$. The depth of cut was kept as constant i.e., $0.5 \mathrm{~mm}$. Surface roughness measurement was carried out on the machined surfaces using a TIME surface roughness tester (TR100). The Piezoelectric stylus was used for taking the surface roughness measurements. Three measurements were made on the machined surface at three different locations and the average value was taken.
A part of the base work piece material (before machining) was subjected to measurements of bulk crystallographic texture. The measurements were obtained at the mid thickness sections of the rolling plane (containing rolling directions (RD) and transverse directions (TD)). All samples were electro polished using the standard technique [15]. For the bulk texture measurement, a PANalytical materials research diffraction (PANalytical, Almelo, The Netherlands) system was used. The orientation distribution functions (ODFs) were obtained through the inversion of four incomplete X-ray pole figures and the software MTM-FHM [16]. The software uses the standard series-expansion technique [17].

\section{Results and Discussions}

The machining tests were conducted with different cutting parameters and the surface roughness was measured. Experimental results for the surface roughness are given in Table 4. 


\subsection{Effect of Cutting Speed on Surface Roughness}

The influence of cutting speed on surface roughness during dry turning of ASTM A 995 GRADE 4A and 5A are shown in Figures $\mathbf{1}$ and $\mathbf{2}$ respectively for three different feed rates $(0.04,0.08$ and $0.12 \mathrm{~mm} / \mathrm{rev})$.

It is observed in both the figures that the surface finish decreases with cutting speed of up to $100 \mathrm{~m} / \mathrm{min}$. With increasing the cutting speed further, the surface roughness of the machined work pieces seams to increase for both the grades. This is due to the increased friction between work piece and tool interface, which eventually increases the temperature in the cutting zone. Hence the shear strength of the material reduces and the material behaves in a ductile fashion. Moreover the duplex stainless steel is sticky in nature which makes the chips to detach from the work piece with utmost difficulty, thereby increasing the surface roughness.

The decrease in surface roughness with increasing cutting speed up to $100 \mathrm{~m} / \mathrm{min}$ is due to the decreasing built up edge (BUE) formation tendency with increasing cutting speed. However, further increase in cutting speed causes an increase in surface roughness. This can be attributed to the increasing cutting tool nose wear at higher cutting speeds of 120,140 and $180 \mathrm{~m} / \mathrm{min}$. It can also be observed that the minimum Ra of machined surfaces is obtained when cutting speed is at $100 \mathrm{~m} / \mathrm{min}$.

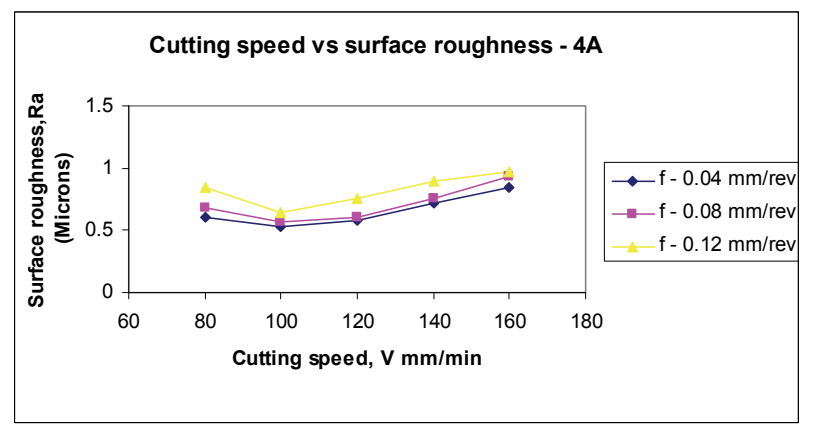

Figure 1. Cutting speed vs. Surface finish-4A.

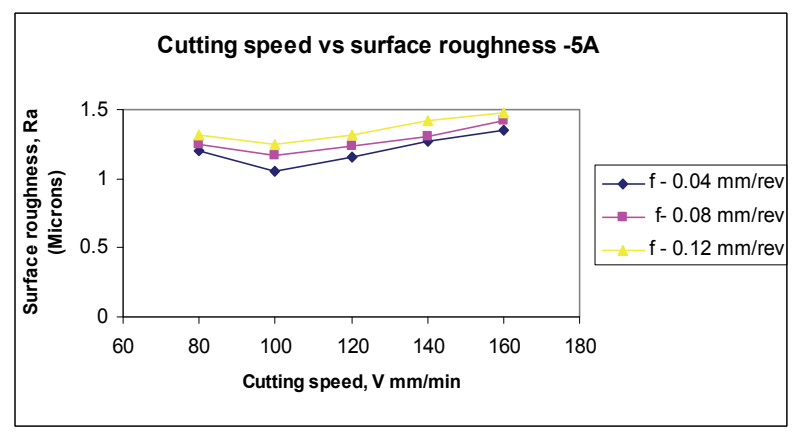

Figure 2. Cutting speed vs. Surface finish-5A.

\subsection{Effect of Feed Rate on Surface Roughness}

Figure 3 shows the influence of feed rate on surface roughness during dry turning of ASTM A 995 GRADE $4 \mathrm{~A}$ with five different cutting speeds $(80,100,120,140$ and $160 \mathrm{~m} / \mathrm{min}$ ). Figure 4 shows the influence of feed rate on surface roughness during dry turning of ASTM A 995 GRADE 5A with five different cutting speeds (80, $100,120,140$ and $160 \mathrm{~m} / \mathrm{min}$ ). It is observed that the surface roughness increases with the increase in feed rate.

It can also be observed that the minimum $\mathrm{Ra}$ of machined surfaces is obtained at the feed rate of $0.04 \mathrm{~mm} / \mathrm{rev}$ for both the grades. As the feed rate increased from $0.04 \mathrm{~mm} / \mathrm{rev}$ to $0.12 \mathrm{~mm} / \mathrm{rev}$, the surface roughness values increase linearly in all the selected cutting speeds. This is due to the widening in the area of contact and changes in the force per unit length, resulting in great distortion of sticky chip.

\subsection{Effect of Work Piece Material (Bulk Texture) on Surface Roughness}

The influence of work piece grade on surface roughness during dry turning of ASTM A 995 GRADE 4A and ASTM A 995 GRADE 5A with five different cutting speeds $(80,100,120,140$ and $160 \mathrm{~m} / \mathrm{min})$ and feed rate of 0.04, 0.08 and $0.12 \mathrm{~mm} / \mathrm{rev}$ are shown in Figures 5-7 respectively.

It is observed that the surface finish of the machined

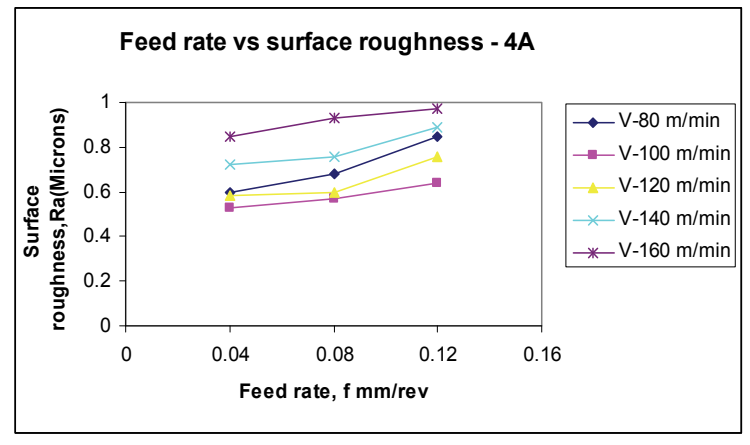

Figure 3. Feed vs. Surface finish-4A.

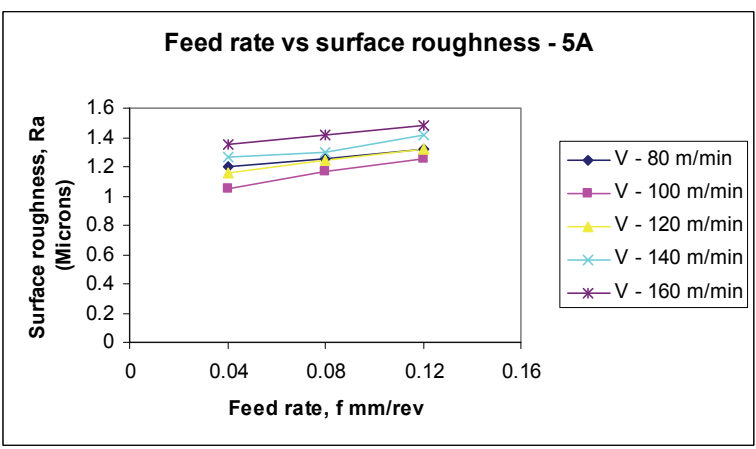

Figure 4. Feed vs. Surface finish-5A. 


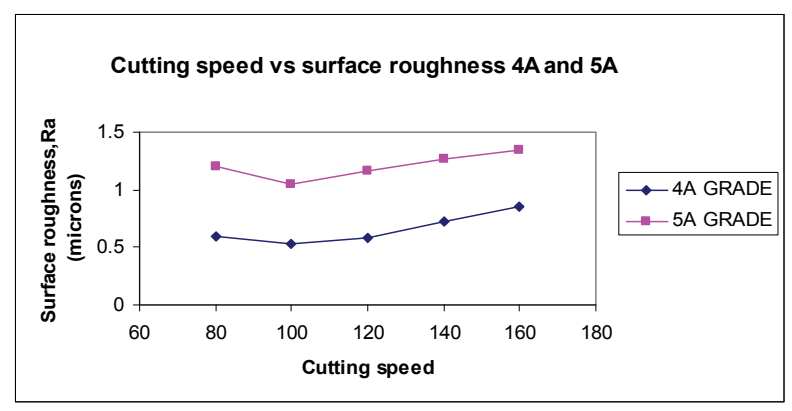

Figure 5. Cutting speed vs. Surface finish for feed rate $0.04 \mathrm{~mm} / \mathrm{rev}$.

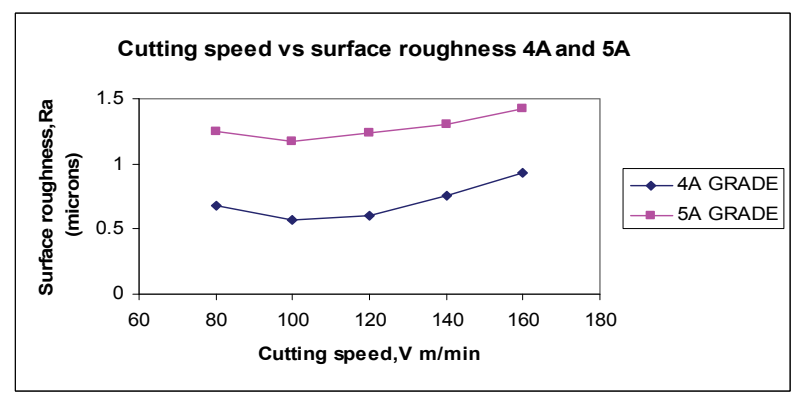

Figure 6. Cutting speed vs. Surface finish for feed rate $0.08 \mathrm{~mm} / \mathrm{rev}$.

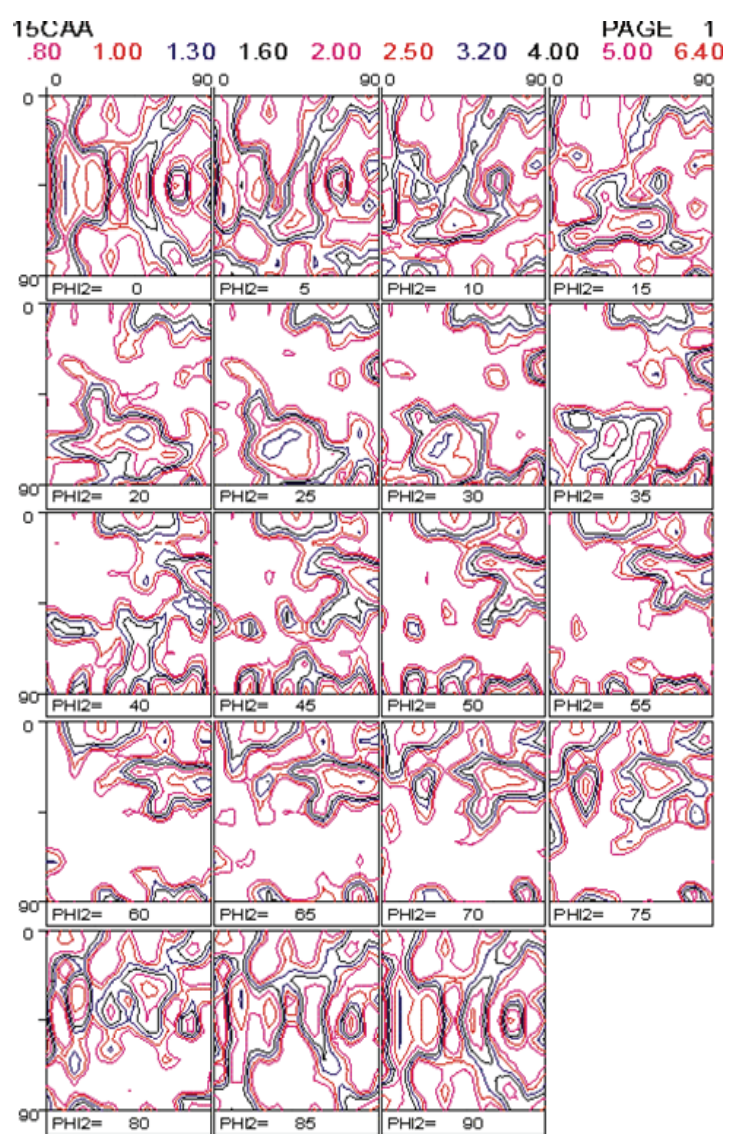

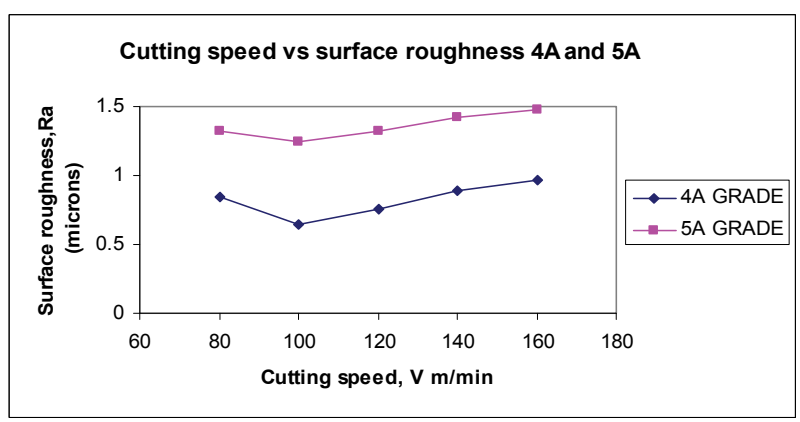

Figure 7. Cutting speed vs. Surface finish for feed rate $0.12 \mathrm{~mm} / \mathrm{rev}$.

work pieces seams to be better with $4 \mathrm{~A}$ grade material than $5 \mathrm{~A}$ grade material in all the cutting speeds and feed rates. Generally stainless steels are regarded as more difficult to machine than carbon and low alloy steels due to their high strength and ductility, high work hardening tendency and poor thermal conductivity. In addition, variations in the chemical compositions of different grades of duplex stainless steels lead to the difference in the formation of micro grains. These grain structure and orientation (Texture) determine the mechanical properties of the base work piece material. The bulk texture formation in austenite and ferrite phase of grade 4A and $5 \mathrm{~A}$ are shown in Figures 8 and 9 respectively.

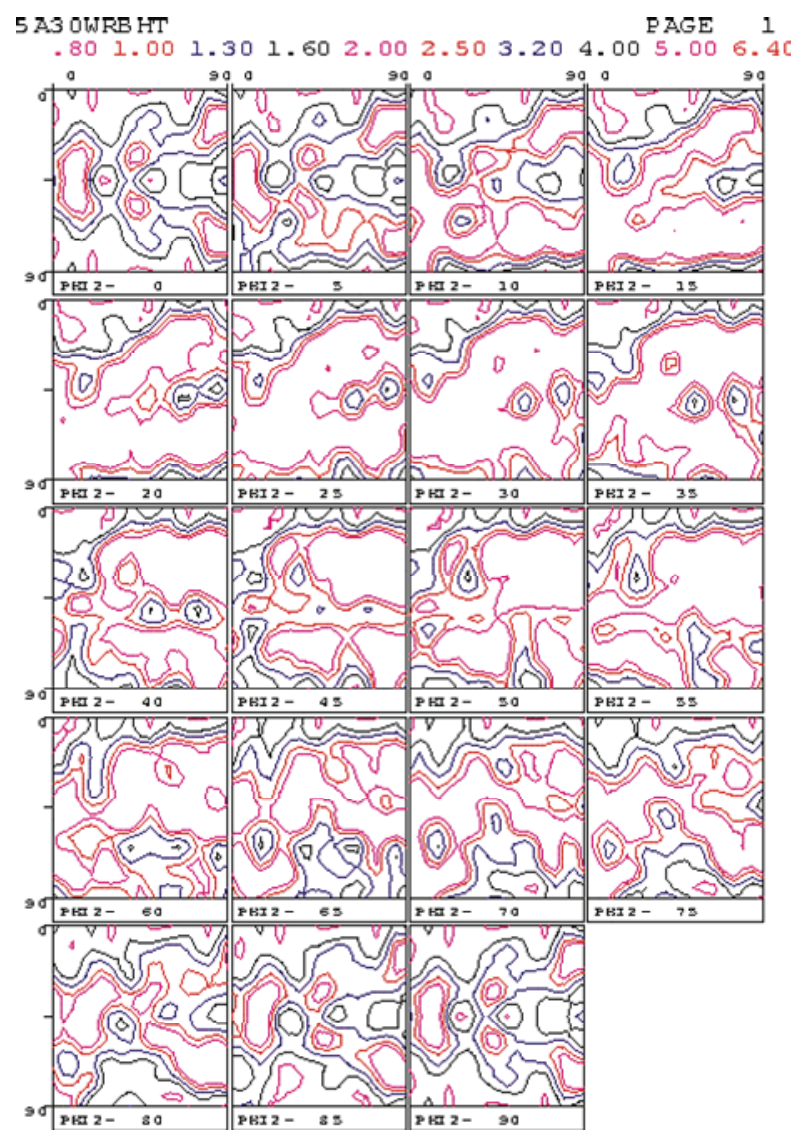




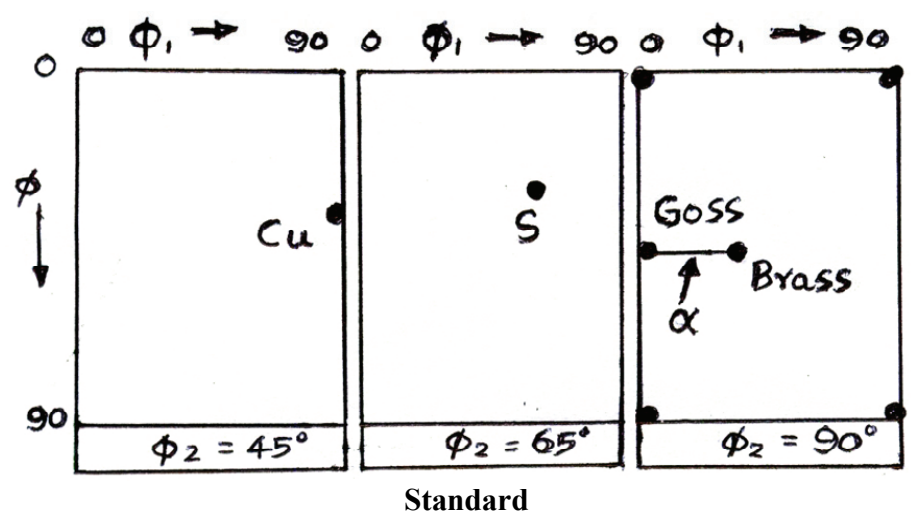

Figure 8. ODFs of austenite phase.

$15 \mathrm{CAF}$

801.001 .301 .602 .002 .503 .204 .005 .006 .40

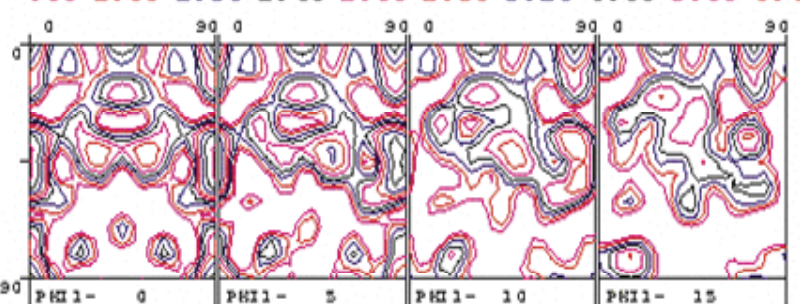

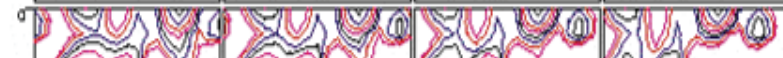

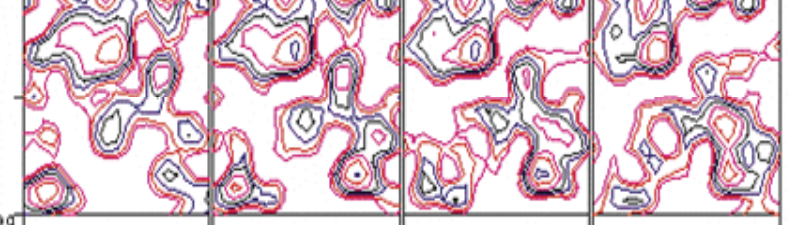

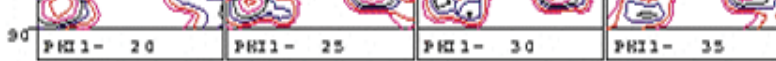

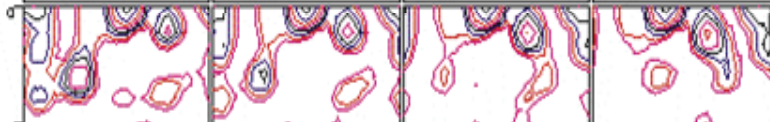

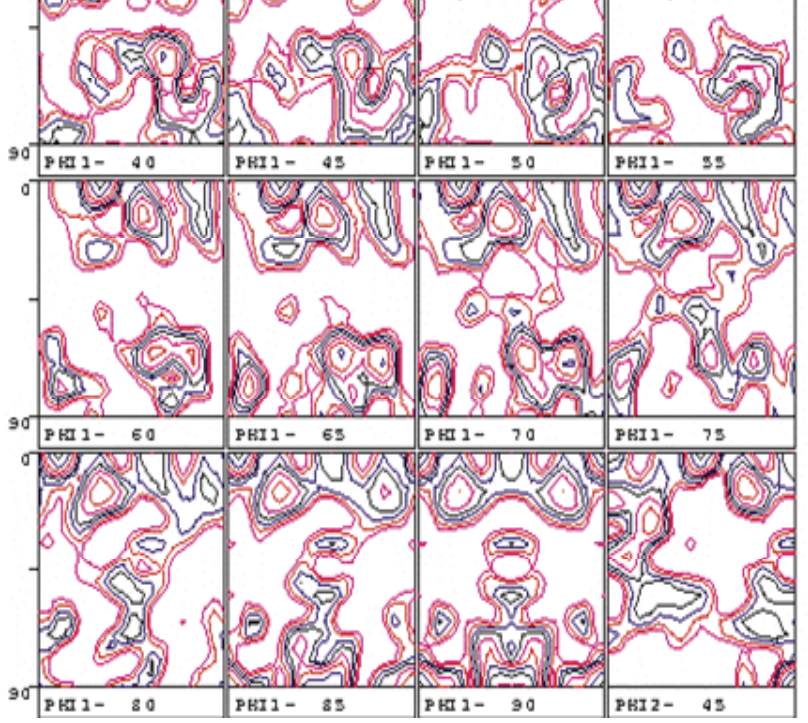

5 A.3 ON RBHT

PAGE 1

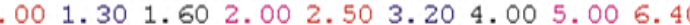

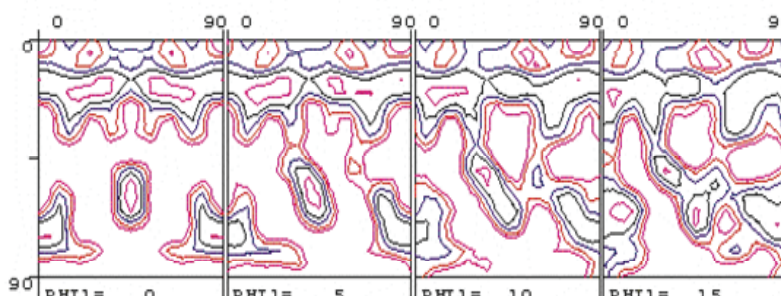

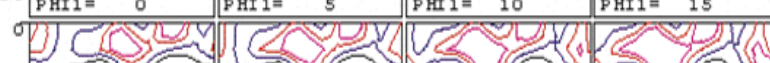
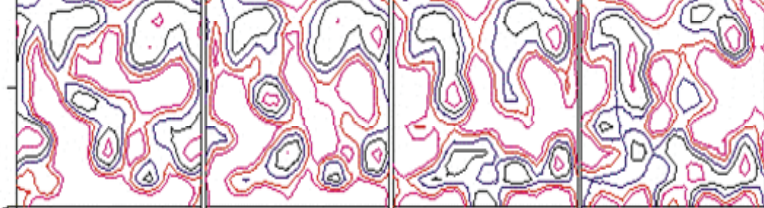

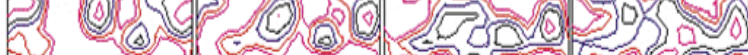
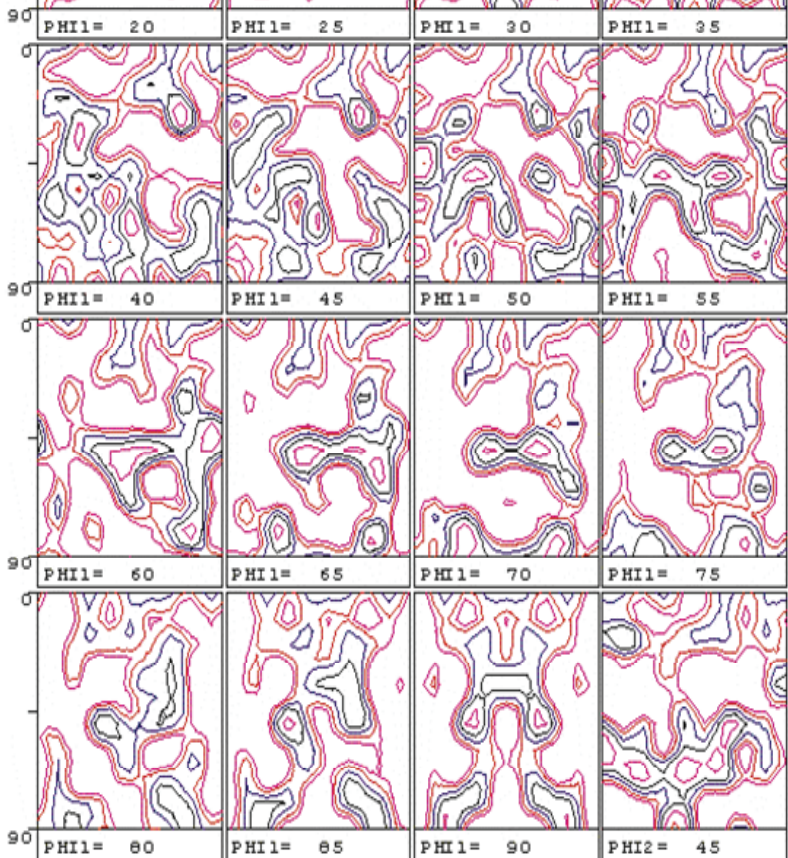


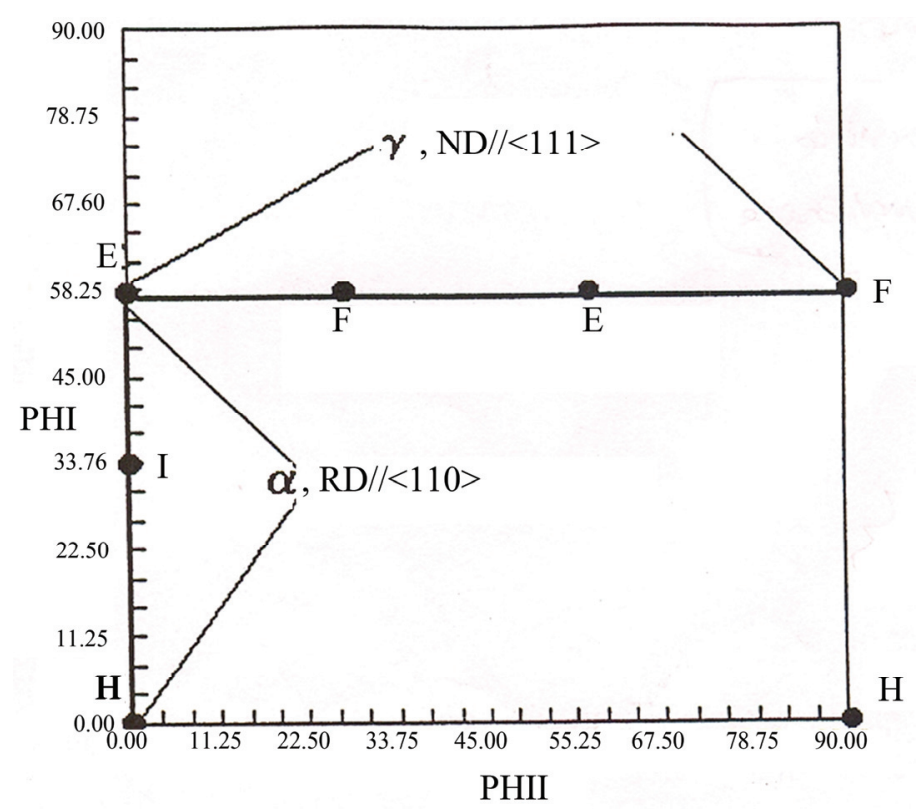

Standard

Figure 9. ODFs of ferrite phase.

Alpha fiber and beta fiber can be noticed in both the standard ODFs of austenite and ferrite. This fiber texture is considered to be the contributing factor for the formation of preferred orientation that lead to better mechanical properties, particularly deep drawability with higher hardness [18]. The alpha ferrite and gamma austenite are supposed to have $<100>$ and $<110>$ fiber textures respectively but only partial fibers are visible in both the ODF's of 4A and 5A alloys. The formation of fiber texture that connects Goss and Brass orientations in the ODF of austenite phase is relatively better in $4 \mathrm{~A}$ when compared to that in ODF of austenite phase of 5A alloy. Therefore this fiber texture would have contributed to better surface finish of machined $4 \mathrm{~A}$ alloy than that of machined 5A alloy.

\section{Conclusions}

Dry turning tests were performed on ASTM A 995 GRADE 5A and ASTM A 995 GRADE 4A duplex stainless steels using TiC and TiCN coated carbide cutting tools. The influence of cutting speed, feed rate and bulk texture on surface roughness was investigated. Based on the results obtained; the following conclusions can be drawn.

Cutting speed is found to have a significant effect on the roughness of the machined surface. With increasing cutting speed, surface roughness values decreases until a minimum value and then increases. Higher surface roughness values at lower cutting speeds are attributed to the BUE formation tendency. Wear of cutting edge nose radius is responsible for the high surface roughness values at higher cutting speeds. Feed rate is found to have a significant effect on the roughness of the machined surface. Better surface finish is noticed at lower feed rate than in higher feed rate. Grade 4A yields better surface finish at all cutting speeds and feed rates employed than in Grade 5A which is attributed to the presence of partial fiber texture in the austenite phase of $4 \mathrm{~A}$ work piece material.

\section{Acknowledgements}

This work is supported by National Facility of Texture and Orientation Imaging Microscopy-Dept of Science and Technology, India at IIT-Bombay and Karunya University-Coimbatore, India (Karunya Short Term research Grant). The authors are grateful to Dr. S. Darius Gnanaraj, Dr. A. S. Varadarajan and Mr. Jones Robin, Karunya University for their technical support. The authors are also grateful to Prof K. Smiles Mascarenhas, CIETCoimbatore for his help in improving the write-up (English language) of this article.

\section{References}

[1] J. R. Davis, "ASM Specialty Handbook Stainless Steels," 2nd Edition, ASM International, Ohio, 1996.

[2] R. Venkata Rao, "Machinabilty Evaluation of Work Materials Using Graph Theory and Analytic Hierarchy Process Methods," Manufacturing Technology, Vol. 28, No. 3-4, 2004, pp. 221-227. 
[3] I. Ciftci, "Machining of Austenitic Stainless Steels Using CVD Multi-Layer Coated Cemented Carbide Tools," Tribology International, Vol. 39, No. 6, 2006, pp. 565-569.

[4] I. Korkut, M. Kasap, I. Ciftci and U. Sekar, "Determination of Optimum Cutting Parameters during Machining of AISI 304 Austenitic Stainless Steel," Materials \& Design, Vol. 25, No. 4, 2004, pp. 303-305.

[5] J. Paro, H. Hanninen and V. Kauppinen, "Tool Wear and Machinabilty of HIPed P/M and Conventional Cast Duplex Stainless Steels," Wear, Vol. 249, No. 3-4, 2001, pp. 279-284.

[6] T. Akasawa, H. Sakurai, M. Nakamura, T. Tanaka and K. Takano, "Effects of Free-Cutting Additives on the Machinabilty of Austenitic Stainless Steel," Journal of Materials Processing Technology, Vol. 143-144, 2003, pp. 66-71.

[7] S. Agrawal, A. K. Chakrabarti and A. B. Chattopadhyay, "A Study of the Machining of Cast Austenitic Stainless Steel with Carbide Tools," Journal of Materials Processing Technology, Vol. 52, No. 2-4, 1995, pp. 610-620.

[8] D. O'Sullivan and M. Cotterell, "Machinability of Austenitic Stainless Steel SS303," Journal of Materials Processing Technology, Vol. 124, No. 1-2, 2002, pp. 153-159.

[9] J. Paro, H. Hanninen and V. Kauppinen. "Tool Wear and Machinabilty of X5 $\mathrm{Cr}$ Mn N 188 Stainless Steels," Journal of Materials Processing Technology, Vol. 119, No. 1-3, 2001, pp. 14-20.

[10] M. Y. Noordin, V. C. Venkatesh and S. Sharif, "Dry Turning of Tempered Martensitic Stainless Tool Steel Using Coated Cermet and Coated Carbide Tools," Journal of Materials Processing Technology, Vol. 185, No. 1-3, 2007, pp. 83-90.

[11] S. Thamizhmanii and S. Hasan, "Measurement of Surface Roughness and Flank Wear on Hard Martensitic
Stainless Steel by CBN and PCBN Cutting Tools," Journal of Achievements in Materials and Manufacturing Engineering, Vol. 31, No. 2, 2008, pp. 415-421.

[12] M. Anthony Xavior and M. Adithan, "Determining the Influence of Cutting Fluids on Tool Wear and Surface Roughness during Turning of AISI 304 Austenitic Stainless Steel," Journal of Materials Processing Technology, Vol. 209, No. 2, 2009, pp. 900-909.

[13] M. Kiran Kumar, I. Samajdar, N. Venkatramani, G. K. Dey, R. Tewari, D. Srivastava and S. Banerjee, "Explaining Absence of Texture Development in Cold Rolled Two-Phase $\mathrm{Zr}-2.5$ wt\% Nb Alloy," Acta Materialia, Vol. 51, No. 3, 2003, pp. 625-624.

[14] P. Chandramohan, S. S. Mohamed Nazirudeen and S. S. Ramakrishnan, "Studies on Production and Thermo Mechanical Treatment of $0.32 \%$ Nitrogen Alloyed Duplex Stainless Steel," Journal of Materials Engineering and Performance, Vol. 17, No. 2, 2008, pp. 271-279.

[15] F. Gauzzi, R. Montanari, G. Principi and M. E. Tata, "AISI 304 Steel: Anomalous Evolution of Martensitic Phase Following Heat Treatments at $400^{\circ} \mathrm{C}$," Materials Science and Engineering A, Vol. 438-440, 2006, pp. 202-206.

[16] F. Gauzzi, R. Montanari, G. Principi, A. Perin and M. E. Tata, "Martensite Formation during Heat Treatments of AISI 304 Steel with Biphasic Structure," Materials Science and Engineering A, Vol. 273-275, 1999, pp. 443-447.

[17] N. Akdut, J. Foct and G. Gottstein, "Cold Rolling Texture Development of $\alpha / \gamma$ Duplex Stainless Steels,' Steel Research, Vol. 67, No. 10, 1996, pp. 450-455.

[18] J. B. Clark, R. K. Garrett, T. L. Jungling, R. A. Vandermeer and C. L. Vold, "Effect of Processing Variables on Texture and Texture Gradients in Tantalum," Metallurgical and Materials Transactions A, Vol. 22, No. 9, 1991, pp. 2039-2048. 